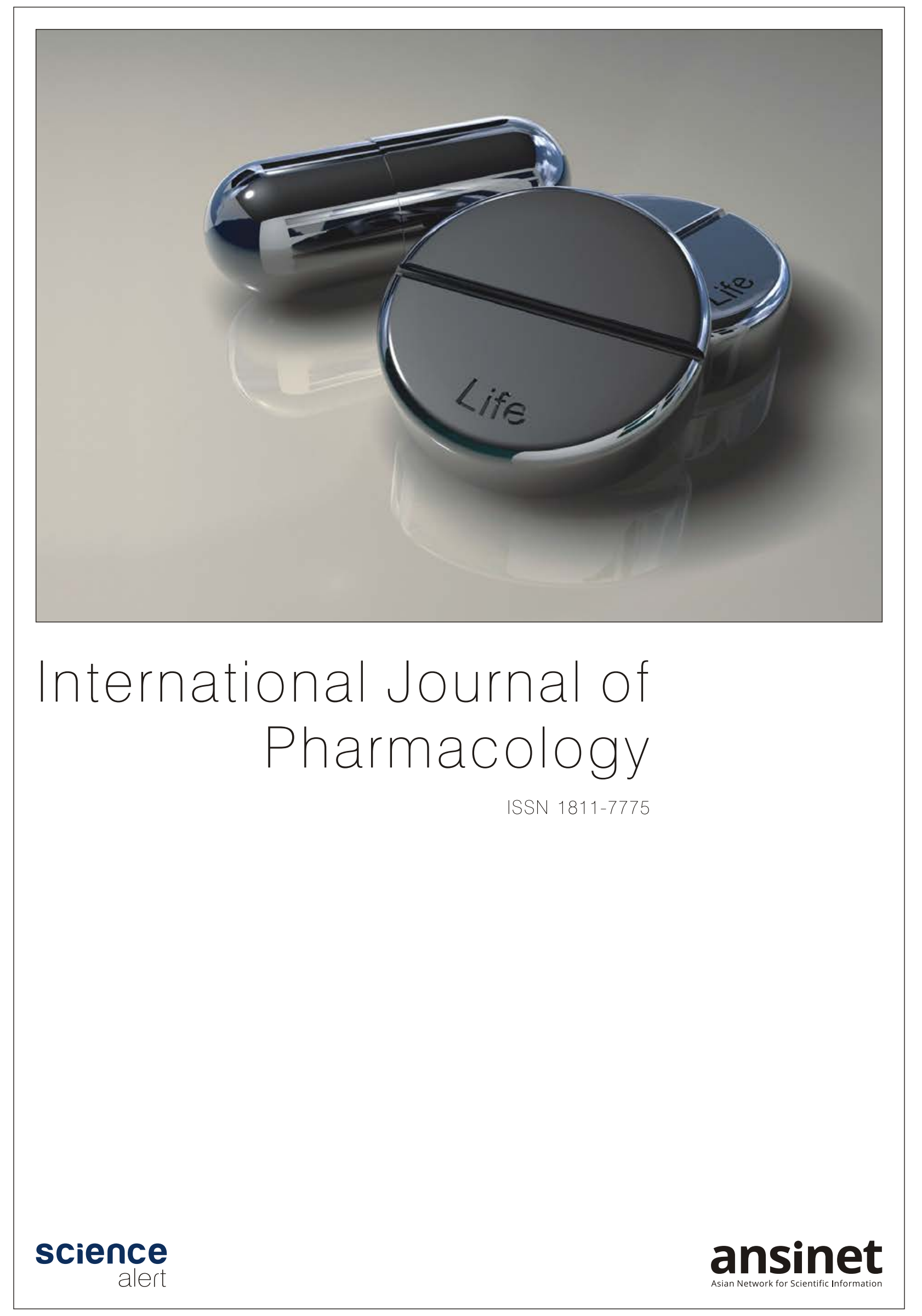


International Journal of Pharmacology 7 (4): 471-477, 2011

ISSN 1811-7775 / DOI: 10.3923/ijp.2011.471.477

(C) 2011 Asian Network for Scientific Information

\title{
Biochemical and Histological Responses of Hepatotoxic Rats Fed Musa paradisiaca L. Supplemented Diet
}

\author{
E.E.J. Iweala, I.C. Obichi and O.E. Omotosho \\ Biochemistry and Molecular Biology Unit, Department of Biological Sciences, \\ Covenant University, P.M.B 1023, Ota, Ogun State, Nigeria
}

\begin{abstract}
Some biochemical and histological effects of consumption of Musa paradisiaca-supplemented diet in hepatotoxic rats were investigated. Twenty-four rats were divided into four hepatotoxic and non-hepatotoxic groups and fed a Musa paradisiaca-supplemented diet. The parameters measured included alanine transaminase, aspartate transaminase, total protein, glucose, total triglycerides, total cholesterol, reduced glutathione, lipid peroxidation and packed cell volume. Histological changes in tissue sections of liver and testes were also examined. The results obtained showed that alamine transaminase and aspartate transaminase did not significantly change except in the hepatotoxic control group which showed an increase in aspartate transaminase. Cholesterol and triglycerides were significantly $(\mathrm{p}<0.05)$ increased in the hepatotoxic group fed Musa paradisiaca-supplemented diet. Protein and reduced glutathione levels were significantly $(\mathrm{p}<0.05)$ increased in non-hepatotoxic rats fed Musa paradisiaca-supplemented. Lipid peroxidation, glucose and PCV levels were not significantly altered in all the groups. The consumption of a Musa paradisiaca-supplemented diet did not significantly change the weight of the animals. Histological observations of tissue sections of liver showed necrosis in the hepatotoxic rats and varying regeneration in the groups fed Musa paradisiacasupplemented diet while there were no changes in the histology of the testes in all the groups.
\end{abstract}

Key words: Musa paradisiaca, alanine transaminase, aspartate transaminase paracetamol, plant food, triglycerides, cholesterol, reduced glutathione

\section{INTRODUCTION}

Several tropical plant foods have been reported to have hepatoprotective properties (Bitsindou and Lejoly, 1993; Iweala and Osundiya, 2010). This is due to their content of phytochemicals such as phenolic compounds, alkaloids, coumarins, flavonoids and lignans (Sharma et al., 2002). Tropical fruits such as plantain constitute a staple food crop and contribute substantially to the nutrition of sub tropical local populations (Strosse et al., 2006). Starch is the main component of plantain as well as proteins, fats, ash and dietary fiber (Juarez-Garcia et al., 2006). However there are differences in nutritional composition between varieties and hybrids (Amankwah et al., 2011). Plantains are known to be a great source of calcium, vitamins A, B1, B2, B3, B6, C and minerals such as potassium and phosphorous (Dzomeku et al., 2007a). Musa paradisiaca L. (Plantain) belong to the Musaceae family which are evergreen tropical giant herbs whose fruits can be consumed either as ripe and unripe in several forms; it is either boiled, fried, roasted, steamed, baked or grilled. Other products derived from plantain are chips and flour (Nwokocha and Williams, 2009; Agoreyo et al., 2007; Robinson, 1996; Gopinath, 1995). Studies showed that consumers of plantain prefer certain varieties and processed products (Dzomeku et al., 2007b, 2006). In addition, Plantain is employed in folklore management of diseases such as diabetes, ulcer and wound healing due to its hypoglycemic, anti-ulcerogenic and analgesic properties (Ojewole and Adewunmi, 2003; Eriyamremu et al., 2007; Alvarez-Acosta et al., 2009; Ingale et al., 2009). Recently, the active ingredient for the anti-ulcerogenic properties of plantain banana has been identified as the flavonoid leucocyamidin (Lewis and Shaw, 2001). In spite of the high potential of plantain to generate income, its cultivation is limited by lack of improved varieties (Dankyi et al., 2007). Also plantains especially those cultivated in contaminated soils tend to bioaccumulate heavy metals (Idodo-Umeh and Ogbeibu, 2010). Liver diseases especially drug-induced hepatotoxicity constitute a major cause of morbidity and mortality in man (Ostapowicz et al., 2002). In Nigeria, hepatic damage and other biochemical effects resulting from the abuse of

Corresponding Author: E.E.J. Iweala, Biochemistry and Molecular Biology Unit, Department of Biological Sciences, Covenant University, P.M.B 1023, Ota, Ogun State, Nigeria Tel: $+234(0) 8036738625$ 
drugs such as paracetamol may not be apparent due to its high tolerance and regular consumption of a wide array of plant foods such as unripe plantain. This is the basis of this preliminary study aimed at investigating the hepatoprotective potentials and other biological effects associated with consumption of unripe fruits of Plantain in paracetamol-induced hepatotoxic rats.

\section{MATERIALS AND METHODS}

This study was carried out between 7 th December, 2009 and 7th March, 2010 at the department of Biological Sciences, Covenant University, Ota, Ogun State, Nigeria.

Processing of Musa paradisiaca L. (Plantain) fruits: Fresh unripe fruits of Musa paradisiaca L. (Plantain) purchased from a local market in Ota, Ogun state, SouthWestern Nigeria were washed, peeled, cut into small pieces, air-dried and ground to a coarse powdered form with a hammermill. The proximate composition of the powdered Musa paradisiaca fruits was determined according to the procedure of AOAC (1975) and considered in the formulation of experimental diets.

Formulation of experimental diets: Two experimental diets namely control diet and Musa paradisiacasupplemented diets were formulated using commercially available feedstuffs including maize, corn flour, fish meal, groundnut meal, bone meal and vitamin premix. The control diet was formulated without incorporation of Musa paradisiaca fruit powder while the Musa paradisiaca-supplemented diets were formulated by incorporating $10 \%$ of Musa paradisiaca fruit powder.

Experimental design: Twenty-four male albino rats (Wistar strain) aged four to six weeks old and with an average weight of $50-80 \mathrm{~g}$ were selected for the study. The rats were randomly distributed into four experimental groups including non-hepatotoxic control, hepatotoxic control, non-hepatotoxic fed 10\% Musa paradisiacasupplemented diet and hepatotoxic fed 10\% Musa paradisiaca-supplemented diet. The rats in nonhepatotoxic control and hepatotoxic control groups were fed control diet while those in non hepatotoxic fed 10\% Musa paradisiaca- supplemented diet and hepatotoxic fed $10 \%$ Musa paradisiaca-supplemented diet groups were fed 10\% Musa paradisiaca-supplemented diet. All the animals were given their various feed and water ad libitum for sixty (60) days. Seven days prior to the end of feeding, hepatotoxicity was induced in animals in the hepatotoxic experimental groups by daily oral administration with $3 \mathrm{~g} \mathrm{~kg}^{-1}$ body weight of paracetamol while those in non-hepatotoxic groups were administered with the vehicle (distilled water) only. The weight of animals in all the groups were measured weekly throughout the experimental period. All the animal experiments were approved by the Covenant University institutional ammal ethics committee in accordance with the guidelines of Committee for the Purpose of Supervision and Control of Experiments on Animals (CPCSEA, 2003).

Collection of blood and tissue samples: At the end of feeding, all the animals were anesthetized and blood samples collected in heparinized bottles while serum samples were collected in non heparinized bottles and allowed to clot before being centrifuged at $5000 \mathrm{rpm}$ for $10 \mathrm{~min}$.

The livers and testes were quickly excised, washed and preserved in $10 \%$ formyl saline for histological studies.

Determination of biochemical parameters: Serum levels of aspartate aminotransferase (AST) and alamine aminotransferase (ALT) and blood glucose levels were determined using test kits produced by Cypress diagnostics, Belguim. Triglycerides and cholesterol were determined using test kits supplied by Linear chemicals SL, Spain. Total protein was determined by the Lowry method (Lowry et al., 1951). Reduced glutathione was determined according to the method described by Ellman (1959). Lipid peroxidation was determined by the TBARS method of Buege and Aust (1978). PCV was determined according to methods described by Dacie and Lewis (1990).

Histological examination of tissues: Paraffin tissue sections $(5-10 \mu)$ of liver and testes were prepared, stained with haematoxylin-eosin and mounted in a neutral medium. Histological examinations were done on the tissues according to procedures described by Disbrey and Rack (1970).

Statistical analysis: Data obtained are expressed as Mean \pm SEM for triplicate determinations. One-way Analysis of Variance (ANOVA) for a completely randomized design was used to analyze data. Values were considered significant at $\mathrm{p}<0.05$. All the statistics were estimates done with SPSS software.

\section{RESULTS AND DISCUSSION}

Paracetamol is usually classified along with nonsteroidal anti-inflammatory drugs (NSAIDS), but is not considered one, rather is part of the class of drugs known 
as aniline analgesics. Hepatic damage in humans and animals associated with high doses of such analgesics is linked to one of their highly reactive metabolite called $N$-acetyl- $p$-benzoquinoneimine (NAPQI) (Ray et al., 1996). NAPQI rapidly reacts with hepatic reduced glutathione (GSH) leading to its depletion and resulting in hepatocellular damage (Mitchell et al., 1973). Several plant products have been investigated for their hepatoprotective properties using Paracetamol as a hepatotoxicant (Suresh et al., 2006).

The effect of the experimental diets on weight before and after induction of hepatic damage is shown in Table 1. Musa paradisiaca-supplemented diet caused varying percentage weight gains in all the groups, which were not statistically significant when compared to the controls. However the percentage weight gain reduced after the induction of hepatotoxicity. The consumption of plantain which did not significantly affect the weight of the animals could be as a result of unavailability of nutrients especially carbohydrate and protein contained in plantain (Foy and Parratt, 1960). Also, liver damage could affect body weight by interfering with its function of processing of nutrients and making them unavailable for growth.

There were no significant changes in blood glucose concentration in the rats fed Musa paradisiacasupplemented diet which suggests that its consumption could reduce the high blood concentration of glucose seen in diabetic conditions with associated liver damage. This observation agrees with the finding reported in several studies done on plantain indicating its hypoglycemic activities (Dhanabal et al., 2005; Oke et al., 1999).
Protein levels were significantly increased $(\mathrm{p}<0.05)$ only in non-hepatotoxic groups fed $10 \%$ Musa paradisiaca-supplemented diet which indicates that plantain is a good source of protein (Foy and Parratt, 1960).

Table 2 shows that the glutathione level was increased in the non-hepatotoxic groups fed $10 \%$ Musa paradisiaca-supplemented diet indicating that plantain consumption increased its synthesis (Pari and Umamaheswari, 2000). Increase in glutathione is associated with protection against oxidative stress induced by free radicals and prevention of diseases (Wu et al., 2004).

The result shown in Table 2 also indicates that the animals in the hepatotoxic groups fed $10 \% \mathrm{Musa}$ paradisiaca-supplemented diet had a high value of cholesterol. Paracetamol may synergistically interfere with cholesterol metabolism when combined with plantain (Bowry and Stocker, 1993). Plantain however reduces cholesterol (Gould et al., 1998). Increase in cholesterol level is a risk factor associated with arteriosclerosis and cardiovascular disease (Cooper, et al., 2007). Hence, consumption of plantain and non prescribed high dose of paracetamol as shown in this study may promote cardiovascular diseases.

Triglyceride concentration was significantly increased $(\mathrm{p}<0.05)$ in the hepatotoxic groups and hepatotoxic group fed $10 \%$ Musa paradisiacasupplemented diet, respectively. High levels of triglycerides, LDL-Cholesterol and VLDL-Cholesterol have been associated with heart disease (Nikkila, 1984). Paracetamol could cause liver damage thereby interfering with the release of fatty acids into the blood.

Table 1: Weight changes Prior to and after Paracetamol- induced hepatotoxicity in hepatotoxic and non hepatotoxic rats fed Musa paractisiaca-supplemented

\begin{tabular}{|c|c|c|c|c|}
\hline Weight change & $\begin{array}{l}\text { Non-hepatotoxic } \\
\text { Control group }\end{array}$ & $\begin{array}{l}\text { Hepatotoxic } \\
\text { Control group }\end{array}$ & $\begin{array}{l}\text { Non-hepatotoxic group } \\
\text { fed } 10 \% \text { Musa paractisiacal- } \\
\text { supplemented diet }\end{array}$ & $\begin{array}{l}\text { Hepatotoxic group fed } \\
10 \% \text { Musa parartisiaca- } \\
\text { supplemented diet }\end{array}$ \\
\hline Prior to hepatotoxicity (\%) & 23.7 & 24.1 & 28.3 & 29.5 \\
\hline After hepatotoxicity (\%) & 2.5 & 22.8 & 17.0 & 26.7 \\
\hline
\end{tabular}

Table 2: Biochemical parameters in hepatotoxic and non hepatotoxic rats fed Musa paractisiaca-supplemented diet

\begin{tabular}{lcccc} 
& $\begin{array}{c}\text { Non-hepatotoxic } \\
\text { Control group }\end{array}$ & $\begin{array}{c}\text { Hepatotoxic } \\
\text { Control group }\end{array}$ & $\begin{array}{l}\text { Non-hepatotoxic group } \\
\text { fed 10\% Misa paractisiaca- } \\
\text { supplemented diet }\end{array}$ & $\begin{array}{l}\text { Hepatotoxic group fed } \\
10 \% \text { Misa parartisiaca- } \\
\text { supplemented diet }\end{array}$ \\
\hline Parameter & $135.51 \pm 29.70$ & $109.76 \pm 22.55$ & $146.85 \pm 15.94$ & $191.87 \pm 29.57$ \\
Glucose $\left(\mathrm{mg} \mathrm{dL}^{-1}\right)$ & $5.52 \pm 0.48$ & $6.28 \pm 0.14$ & $6.50 \pm 0.19^{*}$ & $5.60 \pm 0.22$ \\
Protein $\left(\mathrm{mg} \mathrm{mL}^{-1}\right)$ & $0.01 \pm 0.001$ & $0.01 \pm 0.001$ & $0.017 \pm 0.003^{*}$ & $0.016 \pm 0.03$ \\
Reduced glutathione $\left(\mathrm{mM} \mathrm{mL}^{-1}\right)$ & $266.18 \pm 4.33$ & $294.31 \pm 11.41$ & $268.17 \pm 5.56$ & $309.43 \pm 14.78^{*}$ \\
Cholesterol $\left(\mathrm{mg} \mathrm{dL}^{-1}\right)$ & $203.44 \pm 1.90$ & $232.99 \pm 7.55^{*}$ & $211.29 \pm 5.53$ & $238.74 \pm 5.78^{*}$ \\
Trighy cerides $\left(\mathrm{mg} \mathrm{dL}^{-1}\right)$ & $11.71 \pm 1.32$ & $10.15 \pm 0.52$ & $11.18 \pm 1.51$ & $13.13 \pm 0.51$ \\
Lipid peroxidation $\left(\mathrm{n} \mathrm{mol} \mathrm{mL}^{-1}\right)$ & $24.03 \pm 6.11^{*}$ & $11.08 \pm 1.79^{*}$ & $32.96 \pm 12.44$ \\
Aspartate transaminase $\left(\mathrm{IU} \mathrm{L}^{-1}\right)$ & $46.66 \pm 9.17$ & $23.53 \pm 3.97$ & $10.38 \pm 2.27$ & $17.06 \pm 3.26$ \\
Alanine transaminase $\left(\mathrm{IU} \mathrm{L} \mathrm{L}^{-1}\right)$ & $19.00 \pm 10.85$ & $37.50 \pm 2.01$ & $44.00 \pm 1.30$ & $39.40 \pm 2.06$ \\
Packed cell volume $(\%)$ & $43.00 \pm 2.41$ & &
\end{tabular}

*Represents values that are significant $(p<0.05)$ with respect to non-hepatotoxic control 


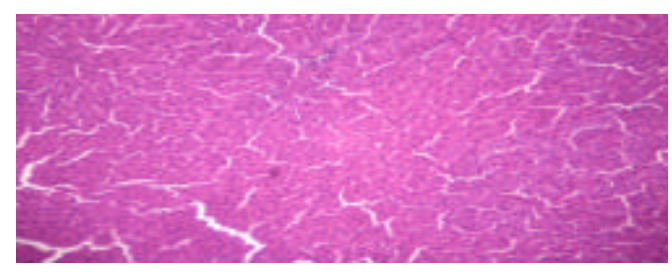

Fig. 1: Photo micrograph of a cross section of liver of non-hepatotoxic rat fed with control diet. MAG. X100

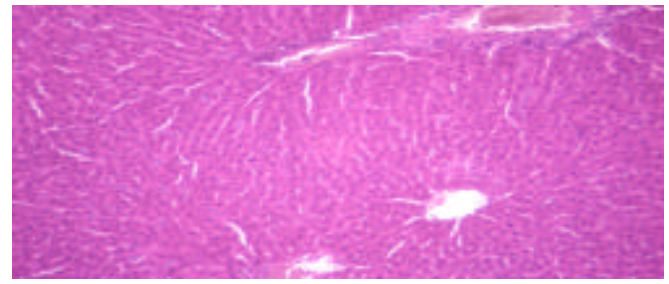

Fig. 2: Photo micrograph of a cross section of liver of non-hepatotoxic rat fed with10\% Musa paradisiaca - supplemented diet. MAG. X100

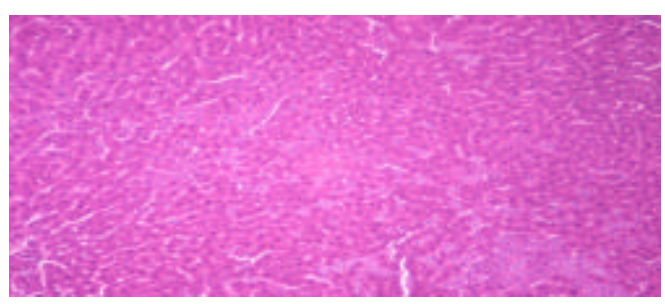

Fig. 3: Photo micrograph of a cross section of liver of hepatotoxic rat fed with control diet. MAG. $\mathrm{X} 100$

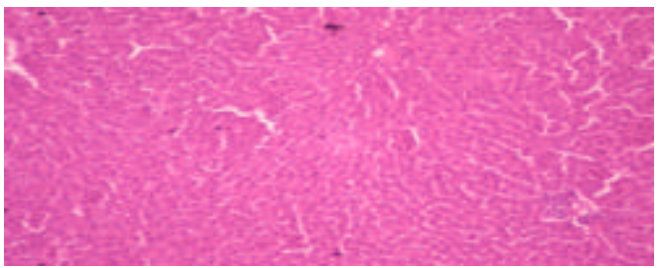

Fig. 4: Photo micrograph of a cross section of liver of hepatotoxic rat fed with $10 \%$ Musa paradisiaca - supplemented diet MAG. X100

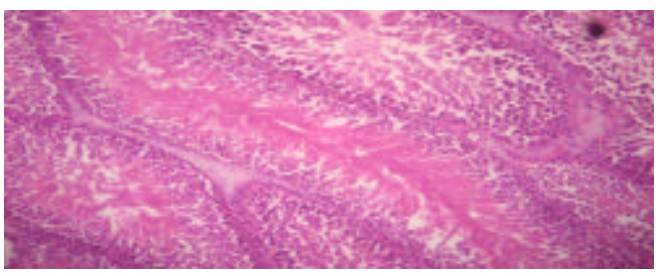

Fig. 5: Photo micrograph of a cross section of testes of non-hepatotoxic rat fed control diet. MAG. $\mathrm{X} 100$

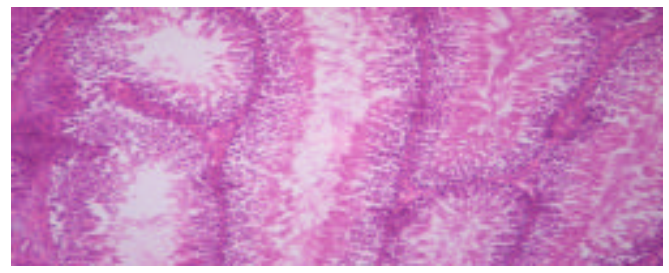

Fig. 6: Photo micrograph of a cross section of testes of non-hepatotoxic rat fed with $10 \%$ Musa paradisiaca - supplemented diet. MAG. X100

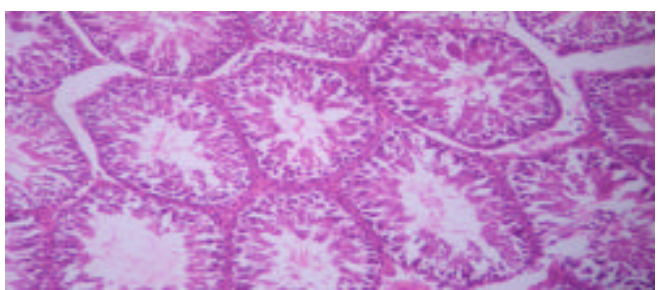

Fig. 7: Photo micrograph of a cross section of testes of hepatotoxic rat fed control diet. MAG. $\mathrm{X} 100$

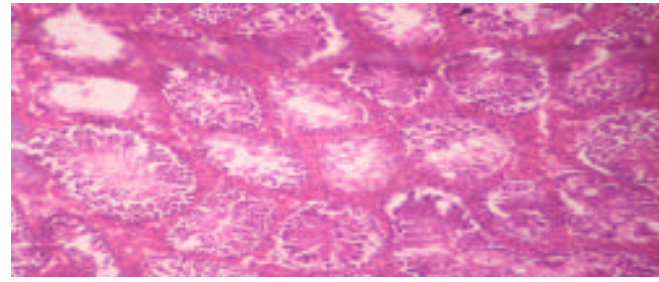

Fig. 8: Photo micrograph of a cross section of testes of hepatotoxic rat fed $10 \%$ Musa paradisiaca supplemented diet. MAG. X100 
In the medical term, high cholesterol and triglyceride levels are referred to as lipid disorder. This lipid disorder increases the risk of atherosclerosis and also heart disease, stroke and high blood pressure (Cooper et al., 2007). However, consumption of plantain has been shown to reduce triglyceride level (Kaimal et al., 2010; Vijayakumar et al., 2009; Gomathy et al., 1989).

There were no significant changes in lipid peroxidation in all the experimental groups. Lipid peroxidation is one of the major causative factors in cell injury produced by free radicals process (Bodis et al., 2000). This indicates that the consumption of plantain stabilized lipid peroxidation in the rats which could be attributed to the presence of antioxidants such as flavanoids (Sies, 1993). Plantain has been reported to reduce lipid peroxidation in animals (Pari and Maheswari, 1999).

The liver enzymes were not significantly altered except AST that was significantly increased $(\mathrm{p}<0.05)$ in the hepatotoxic control group. The liver enzymes, AST and ALT play a role in the metabolism of amino acids. An increase in level of both enzymes may indicate hepatocellular disease, active cirrhosis and metastatic liver tumor (Vaishwanar et al., 1976). Table 2 shows that there was a significant increase of AST level in the hepatotoxic control dosed with paracetamol which could have caused liver damage seen as the increase in the level of AST. Conversely, there was a reduction of AST in the non-hepatotoxic groups fed 10\% Musa paradisiacasupplemented diet. This shows that plantain may possess protective effects on the liver.

There were no significant changes in PCV in all the groups. PCV is of diagnostic importance in paracetamolinduced toxicity and are affected by most bioactive phytochemicals (Patrick-Iwuanyanwu et al., 2007). Paracetamol causes a reduction in the red blood cells which can lead to anemia (Mullick et al., 1973). Consumption of plantain could protect the red blood cells due to its content of blood forming nutrients such as iron. This could explain why there were no changes in the PCV values despite the administration of Paracetamol.

The histological features of the liver of the animals in all the groups are shown in Fig. 1-4 while those of the testes are shown in Fig. 5-8. The liver sections of the rats in the control (Fig. 1) and non-hepatotoxic groups (Fig. 2) fed with Musa paradisiaca - supplemented diet showed less degeneration of hepatocytes while those of the hepatotoxic control group (Fig. 3) showed degeneration with some centrilobular necrosis and haemorrhages. However, Fig. 4 shows that the intensity of centrilobular necrosis was less in the liver sections of the hepatotoxic groups fed 10\% Musa paradisiaca- supplemented diet indicating marked preservation of hepatic architecture. In contrast, the histology of the testes of rats in all the groups showed in Fig. 5, 6, 7 and 8 did not show any noticeable changes.

In conclusion, the hepatoprotective effects of unripe plantain are indicated by some of the biochemical, hematological and histological results obtained in this study. Consumption of plantain could protect against liver damage caused by Paracetamol. Also, there could be a synergistic effect between plantain and paracetamol to increase cholesterol level and this could have consequences in promoting cardiovascular diseases.

\section{REFERENCES}

AOAC, 1975. Official Methods of Analysis. 12th Edn., Association of Official Agriculture Chemists, Washington, DC., ISBN: 0935584242, pp: 811-817.

Agoreyo, B.O., K.D. Golden, H.N. Asemota and A.U. Osagie, 2007. Postharvest biochemistry of the plantain (Musa paradisiacal L.). J. Biol. Sci., 7: 136-144.

Alvarez-Acosta, T., C. Leon, S. Acosta-Gonzalez, H. Parra-Soto, I. Cluet-Rodriguez, M.R. Rossell and J.A. Colina-Chourio, 2009. Beneficial role of green plantain [Musa paradisiacal] in the management of persistent diarrhea: A prospective randomized trial. J. Am. Coll. Nutr., 28: 169-176.

Amankwah, E.A., I. Ayim, K.A. Dzisi and J. Barimah, 2011. Nutritional content and functional properties of french horn, false horn and FHIA-21. Am. J. Food Technol., 6: 322-328.

Bitsindou, M. and J. Lejoly, 1993. Plants used in hepatoprotective remedies in traditional African medicine. ISHS Acta Hort., 332: 73-80.

Bodis, B., O. Karadi, I. Szabo, P. Nemeth, J. Belagyi and G. Mozsik, 2000. Evidence for the involvement of oxygen free radicals in the ethanol-induced late cellular injury in mouse myeloma cells. J. Physiol. Paris, 94: 67-70.

Bowry, V.W. and R. Stocker, 1993. Tocopherol-mediated peroxidation: The prooxidant effect of vitamin $\mathrm{E}$ on the radical-initiated oxidation of human low-density lipoprotein. J. Am. Chem. Soc., 115: 6029-6044.

Buege, J.A. and S.D. Aust, 1978. Microsomal Lipid Peroxidation. In: Methods of Enzymology, Fleischer, S. and L. Packer (Eds.). Academic Press, New York, pp: 302-310.

CPCSEA, 2003. CPCSEA guidelines for laboratory animal facility. Indian J. Pharmacol., 35: 257-274. 
Cooper, A., L. Nherera, N. Calvert and N. O'Flynn and N. Turnbull et al., 2007. Clinical guidelines and evidence review for lipid modification: Cardiovascular risk assessment and the primary and secondary prevention of cardiovascular disease. National Collaborating Centre for Primary Care and Royal College of General Practitioners, London. http://www.nice.org.uk/nicemedia/pdf/CG67fullguid eline.pdf.

Dacie, J.V. and S.M. Lewis, 1990. Practical Haematology. 7th Edn., Churchill Livingstone, London, ISBN: 0443039526.

Dankyi, A.A., B.M. Dzomeku, F.O. Anno-Nyako, A. AduAppiah and G. Antwi, 2007. Plantain production practices in the Ashanti, Brong-Ahafo and Eastern Regions of Ghana. Asian J. Agric. Res., 1: 1-9.

Dhanabal, S.P., M. Sureshkumar, M. Ramanathan and B. Suresh, 2005. Hypoglycemic effect of ethanolic extract of Musa sapientum on alloxan induced diabetes mellitus in rats and its relation with antioxidant potential. J. Herb Pharmacother., 5: 7-19.

Disbrey, B.D. and J.H. Rack, 1970. Histological Laboratory Methods. Livingstone, Edinburgh, ISBN: 0443006946, pp: 56-128.

Dzomeku, B.M., M. Osei-Owusu, A.A. Ankomah, E. Akyeampong and S.K. Darkey, 2006. Sensory evaluation of some cooking bananas in Ghana. J. Applied Sci., 6: 835-837.

Dzomeku, B.M., F. Armo-Annor, K. Adjei-Gyan and S.K. Darkey, 2007a. Consumer preference for three selected Musa Hybrids in Ghana. Am. J. Food Technol., 2: 684-688.

Dzomeku, B.M., E. Adu-Kwarteng and S.K. Darkey, $2007 \mathrm{~b}$. Comparative study on the nutritional composition of two fhia tetraploids fhia-21 (tetraploid french plantain) and fhia-03 (tetraploid cooking banana) in Ghana. Am. J. Food Technol., 2: 452-456.

Ellman, G.L., 1959. Tissue sulfhydryl groups. Arch. Biochem. Biophys., 82: 70-77.

Eriyamremu, G.E., S.O. Asagba, V.E. Osagie, S.I. Ojeaburu and O. Lolodi, 2007. Phospholipid profile of the stomach and duodenum of normal rabbits fed with supplements of unripe pawpaw (Carica papaya) and unripe plantain (Musa sapientum) extract. J. Appl. Sci., 7: 3536-3541.

Foy, J.M. and J.R. Parratt, 1960. A note on the presence of noradrenaline and 5-hydroxytryptamine in plantain (Musa sapientum, var. paradisiaca). J. Pharm. Pharmacol., 12: 360-364.

Gomathy, R., N.R. Vijayalekshmi and P.A. Kurup, 1989. Hypolipidemic principle of the inflorescence stalk of plantain (Musa sapientum). J. Biosci., 14: 301-309.
Gopinath, C.Y., 1995. How to cook a Musa pseudostem. Infomusa, 4: 31-31.

Gould, A.L., J.E. Rossouw, N.C. Santanello, J.F. Heyse and C.D. Furberg, 1998. Cholesterol reduction yields clinical benefit: Impact of statin trials. Circulation, 97: $946-952$.

Idodo-Umeh, G. and A.E. Ogbeibu, 2010. Bioaccumulation of the heavy metals in cassava tubers and plantain fruits grown in soils impacted with petroleum and non-petroleum activities. Res. J. Environ. Sci., 4: $33-41$.

Ingale, S.P., P.L. Ingale and A.M. Joshi, 2009. To study analgesic activity of stem of Musa sapientum Linn. J. Pharm. Res., 2: 1381-1382.

Iweala, E.E.J. and A.O. Osundiya, 2010. Biochemical, haematological and histological effects of dietary supplementation with leaves of Gnetum africanum Welw. on paracetamol-induced hepatotoxicity in rats. Int. J. Pharmacol., 6: 872-879.

Juarez-Garcia, E., E. Agama-Acevedo, S.G. SayagoAyerdi, S.L. Rodriguez-Ambriz and L.A. Bello-Perez, 2006. Composition, digestibility and application in breadmaking of banana flour. Plant Foods Hum. Nutr., 61: 131-137.

Kaimal, S., K.S. Sujatha and S. George, 2010. Hypolipidaemic and antioxidant effects of fruits of Musa AAA (Chenkadali) in alloxan induced diabetic rats. Ind. J Exp. Biol., 48: 165-173.

Lewis, D.A. and G.P. Shaw, 2001. A natural flavonoid and synthetic analogues protect the gastric mucosa from aspirin-induced erosions. J. Nutr. Biochem., 12: $95-100$

Lowry, O.H., N.J. Rosebrough, A.L. Farr and R.J. Randall, 1951. Protein measurement with the folin phenol reagent. J. Biol. Chem., 193: 265-275.

Mitchell, J.R., D.J. Jollow, W.Z. Potter, J.R. Gillette and B.B. Brodie, 1973. Acetaminophen-induced hepatic necrosis: IV. Protective role of glutathione. J. Pharmacol. Exp. Ther., 187: 211-217.

Mullick, F.G., C. Delage and N.S. Irey, 1973. Sickle cell crises associated with drugs. Arch. Environ. Health, 26: $221-222$.

Nikkila, E.A., 1984. Plasma Lipid and Lipoprotein Abnormalities in Diabetes. In: Diabetes and Heart Diseases, Jarret, R.F. (Ed.). Elsevier Science Publishers, Amsterdam, The Netherlands, pp: 134-167.

Nwokocha, L.M. and P.A. Williams, 2009. Some properties of white and yellow plantain (Musa paradisiacal, Normalis) starches. Carbohydrate Polymers, 76: 133-138. 
Ojewole, J.A. and C.O. Adewunmi, 2003. Hypoglycemic effect of methanolic extract of Musa Paradisiacae (Musaceae) green fruits in normal and diabetic mice. Methods Find Exp. Clin. Pharmacol., 25: 453-456.

Oke, J.M., C.J. Achife and O.O. Adefisan, 1999. Hypoglycaemic activity of the alcoholic extract of Musa sapentium. Nig. J. Nat. Prod. Med., 3: 68-70.

Ostapowicz, G., R.J. Fontana, F.V. Schiodt, A. Larson and T.J. Davern et al., 2002. Results of a prospective study of acute liver failure at 17 tertiary care centers in the United States. Ann. Intern. Med., 137: 947-954.

Pari, L. and J.U. Maheswari, 1999. Hypoglycemic effect of Musa sapientum L. in alloxan-induced diabetic rats. J. Ethnopharmacol., 68: 321-325.

Pari, L.J. and J. Umanıaheswari, 2000. Antihyperglycaemic activity of Musa sapientum flowers: Effect on lipid peroxidation in Alloxan diabetic rats. Phytother. Res., 14: 136-138.

Patrick-Iwuanyanwu, K.C., M.O. Wegwu and E.O. Ayalogu, 2007. The protective nature of garlic, ginger and vitamin $\mathrm{E}$ on CCl4-induced hepatotoxicity in rats. Asian J. Biochem., 2: 409-414.

Ray, S.D., V.R. Mumaw, R.R. Raje and M.W. Fariss, 1996. Protection of acetaninophen-induced hepatocellular apoptosis and necrosis by cholesterol hemisuccinate pretreatment. J. Pharmacol. Exp. Ther., 279: 1470-1483.

Robinson, J.C., 1996. Bananas and Plantains. CAB International, Walling ford, UK.
Sharma, S.K., M. Ali and J. Gupta, 2002. Plants having hepatoprotective activity. Phytochem. Pharmacol., 2: $253-270$.

Sies, H., 1993. Strategies of antioxidant defence. Eur. J. Biochem., 215: 213-219.

Strosse, H., H. Schoofs, B. Panis, E. Andre, K. Reyniers and R. Swennen, 2006. Development of embryogenic cell suspensions from shoot meristematic tissue in bananas and plantains (Musa sp.). Plant Sci., 170: 104-112.

Suresh, K.S.V., C. Sujatha, J. Syanıla, B. Nagasudha and S.H. Mishra, 2006. Protective effect of root extract of Operculina turpethum L. against paracetamolinduced hepatotoxicity in rats. Indian J. Pharm. Sci., 68: 32-35.

Vaishwanar, I., C.N. Kowale and G.G. Jiddewar, 1976. Effect of two ayurvedic drugs Shilajeet and Eclinol on changes in liver and serum lipids produced by carbontetrachloride. Indian J. Exp. Biol., 14: 57-58.

Vijayakumar, S., G. Presannakumar and N.R. Vijayalakshmi, 2009. Investigations on the effect of flavonoids from banana, Musa paradisiacal L. on lipid metabolism in rats. J. Diet. Suppl., 6: 111-123.

Wu, G., Y.Z. Fang, S. Yang, J.R. Lupton and N.D. Turner, 2004. Glutathione metabolism and its implications for health. J. Nutr., 134: 489-492. 